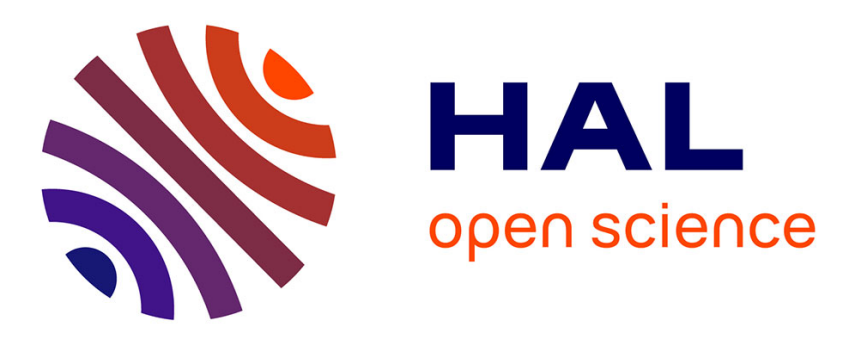

\title{
Fluorinated carbonaceous nanoparticles as active material in primary lithium battery
}

\author{
Alain Tressaud, Henri Groult
}

\section{To cite this version:}

Alain Tressaud, Henri Groult. Fluorinated carbonaceous nanoparticles as active material in primary lithium battery. Journal of Fluorine Chemistry, 2019, 219, pp.1-9. 10.1016/j.jfluchem.2018.12.007 . hal-02007616

\section{HAL Id: hal-02007616 https://hal.science/hal-02007616}

Submitted on 5 Feb 2019

HAL is a multi-disciplinary open access archive for the deposit and dissemination of scientific research documents, whether they are published or not. The documents may come from teaching and research institutions in France or abroad, or from public or private research centers.
L'archive ouverte pluridisciplinaire HAL, est destinée au dépôt et à la diffusion de documents scientifiques de niveau recherche, publiés ou non, émanant des établissements d'enseignement et de recherche français ou étrangers, des laboratoires publics ou privés. 


\title{
Fluorinated carbonaceous nanoparticles as active material in primary lithium battery
}

\author{
A. Tressaud ${ }^{\mathrm{a}}$ and H. Groult ${ }^{\mathrm{b}}$ \\ ${ }^{a}$ Institut de Chimie de la Matière Condensée de Bordeaux ICMCB-CNRS, Université Bordeaux, 87, Av. \\ Dr A. Schweitzer, 33608 Pessac, France \\ ${ }^{a}$ Sorbonne Universités, Univ. UPMC-Paris 6, PHENIX, UMR 8234, 75052 Paris, France
}

\begin{abstract}
In this work, we address the properties of fluorinated carbonaceous nanoparticles (F-CNPs) prepared using a low-temperature process in molten Li-Na-K carbonates at the eutectic composition. The electrochemical performance of these materials is evaluated as the positive electrode of primary lithium ion batteries. Structural analyses show that CNPs are composed of both amorphous and graphitized domains with low crystallinity that induces presence of different types of $\mathrm{C}-\mathrm{O}$ bonds. In contrast with commercial $\mathrm{CF}_{\mathrm{x}}$ materials, F-CNPs do not give rise to a flat potential plateau but exhibit a continuous decrease of the potential. The difference in the electrochemical performance observed for F-CNPs $(\mathrm{CF} \sim 0.43)$ can be significantly noted for high discharge at $1 \mathrm{C}$ rate, for which the discharge potential is about $0.7-0.9 \mathrm{~V}$ higher than that obtained with commercial $\mathrm{CF}_{\mathrm{x}}$ with an increase of the specific capacity to ca. $450 \mathrm{mAh} \cdot \mathrm{g}^{-1}$.
\end{abstract}

Keywords: Carbonaceous nanoparticles; Fluorination; $\mathrm{CF}_{\mathrm{x}}$; X-ray photoelectron spectroscopy; Li-ion batteries

E-mail address: alain.tressaud@icmcb.cnrs.fr 


\section{Introduction}

From several decades, much attention has been devoted to carbon - fluorine compounds used as positive electrode materials for non-rechargeable (primary) lithium battery. The first commercial primary lithium battery using graphite fluorides, $\left(\mathrm{CF}_{\mathrm{x}}\right)_{\mathrm{n}}$ (denoted $\mathrm{CF}_{\mathrm{x}}$ hereafter) as positive electrode was proposed by Watanabe [1,2] and developed in 1970 by Matsushita Battery Industrial. These compounds were prepared from the chemical reaction of fluorine gas with carbon at high temperature $\left(>350{ }^{\circ} \mathrm{C}\right)$ giving rise to compositions up to CF [3]. Thus, these compounds are usually non-stoichiometric with an average deviation value $x$ in the range $0-1.3[2,3]$.

Graphite fluorides generally exhibit very low electrical conductivity, which strongly decreases with increased fluorine contents, i.e. an increase of $x$ in the $\mathrm{CF}_{\mathrm{x}}$ formula, because $\mathrm{C}-\mathrm{F}$ bonds are covalent and carbon atoms are $\mathrm{sp}^{3}$-hybridized. Nevertheless, they present some advantages as positive electrode materials in primary lithium battery such as high cell voltage (about $2.5 \mathrm{~V}$ ), flat discharge potential, long shelf life (> 10 years at room temperature), and large operating temperature range (from -60 to $40{ }^{\circ} \mathrm{C}$ ) [34]. For instance, $\mathrm{CF}$ used in commercial lithium batteries exhibits a theoretical discharge capacity of about $870 \mathrm{Ah} \cdot \mathrm{kg}^{-1}$. The irreversible reduction of graphite fluorides in organic electrolysis obeys to a two-steps mechanism: at first, the electrochemical insertion of lithium cations into the lattice occurs with formation of an intermediate ternary graphite intercalation compound $\mathrm{Li}_{y} \mathrm{CF}_{\mathrm{x}}$ (denoted $\mathrm{Li}-\mathrm{GIC}$ ). Then, the Li-GIC is irreversibly decomposed into carbon and lithium fluoride [4]. Consequently, due to this two-step reduction mechanism, the working voltage of a $\mathrm{CF} / / \mathrm{Li}$ cell is significantly lower than the theoretical difference between electrochemical potential of electrodes; the measured cell voltage is about 1.3-1.5 V. It induces a significant reduction of the accessible gravimetric energy from 3900 to about $2200 \mathrm{Wh} \cdot \mathrm{kg}^{-1}$. In addition, the low electrical conductivity limits the use of graphite fluorides for commercial development.

On the other hand, graphite can react with fluorine gas at temperatures below $100{ }^{\circ} \mathrm{C}$ in the presence of a catalyst such as HF to give fluorine graphite intercalation compounds (F-GICs). In this case, the carbon atoms of the graphene layers keep their $\mathrm{sp}^{2}$ hybridization $[5,6]$. Such compounds have higher voltage but lower capacity than those obtained with $\mathrm{CF}_{\mathrm{x}}$ in a primary lithium battery. F-GICs have higher electrical conductivity compared to $\mathrm{CF}_{\mathrm{x}}$ due to the presence of semi-ionic $\mathrm{C}-\mathrm{F}$ bonding, leading to very high value of $\sigma$, which can reach $1.610^{5} \mathrm{~S} \cdot \mathrm{cm}^{-1}[7]$, whereas the conductivities of stoichiometric CF compounds are about $10^{-14} \mathrm{~S} \cdot \mathrm{cm}^{-1}$ due to covalent $\mathrm{C}-\mathrm{F}$ bonding.

Improvements of the electrochemical performances of C-F compounds have been proposed by using nanoparticles that exhibit higher potential and energy density values. Recently, several papers have been published on the effect of surface modification of $\mathrm{CF}_{\mathrm{x}}$ by chemical routes or by heat-treatment [8-9]. Thus, a positive effect can be obtained with carbon-fluorine nanoparticles since it should combine the properties of $\mathrm{CF}_{\mathrm{x}}$ and nanoscale. The first electrochemical studies on fluorinated nanocarbons in lithium battery have 
been achieved by Hamwi et al. [10] and Touhara et al. [11], and several papers have been published during the last decade on these topics [12-14].

In terms of electrochemical performances, one of the most important parameters is the nature of the carbonaceous starting material and its affinity to react with fluorine at low temperature. In addition, the control of the particle size appears to be another key parameter to enable practical uses in lithium batteries. It is generally assumed that one of the keys for developing such storage devices is linked to the control of the synthesis of nano-scaled materials (nanoparticles or nanostructured materials). The most popular methods for the preparation of electrode materials are currently standard solid-state reactions, chimie douce (soft chemistry), high-energy milling, sputtering (for thin films), co-precipitation followed by heat treatment, chemical vapour deposition, hydrothermal synthesis, etc. Such methods hardly give highly dispersed and small particles, usually without any shape/morphology control. In addition to these methods, the electrochemical deposition process presents several advantages notably the synthesis of powders or thin films with controlled thickness, morphology, and composition of the deposited films by adjusting the operating conditions. Several reports have been devoted to the fluorination of single- [15] or multi-wall nanotubes (MWCNTs) [16-19] and amorphous nanocarbons [20]. By surface modification of $\mathrm{CF}_{\mathrm{x}}$ compounds, high-rate capabilities and new functionalization have been reached [21,22]. More recently, several papers have dealt with fluorinated graphene as the active component of high performance electrodes for primary Li batteries [23-25].

Many papers have been published on the surface modification of $\mathrm{CF}_{\mathrm{x}}$ by chemical or physical treatment [8,26-28]. We have developed during the last decade an original route using molten salts to prepare carbon nanoparticles (denoted CNPs) based on the electro-reduction of fused carbonates between 450 and $700{ }^{\circ} \mathrm{C}$ [29]. It has been shown that the size of the CNPs can be controlled by adjusting the temperature of the molten salts and/or the operation conditions during the electrolysis of the melt. As the control of the particles size plays a key role during the discharge, it is well known that the surface area and interlayer spacing of fluorinated graphene layers are the main factors impacting the discharge potential during the reduction of $\mathrm{CF}_{\mathrm{x}}$.

The objective of this article is to describe optimized CNP materials for primary lithium batteries that requires high power and high energy density, since the main characteristics of the discharge of a $\mathrm{CF}_{\mathrm{x}}$ electrode material is the suppression of the initial voltage delay. To succeed, we propose herewith the synthesis of new types of fluorinated CNPs. CNPs prepared in molten carbonates were fluorinated for obtaining nano-sized powders. Our goal is to succeed in performing the fluorination of the CNPs at low temperature without the use of any precursor or catalyst such as HF, as is conventionally done. Thus, the CNPs prepared in molten carbonates have been fluorinated under $F_{2}$ gas, pure or diluted in Ar, at low temperatures (generally at room temperature) to avoid the strong reactivity of the CNPs with this medium. 
To improve the electrochemical performances of primary Li-batteries, i.e. to find new materials that could give rise to higher potential and energy density values, fluorinated carbon- nanoparticles could be suitable to be used for such power sources, since they should allow combining the intrinsic properties of $\mathrm{CF}_{\mathrm{x}}$ and those of nanosized particles. We present here a series of experiments obtained with CNPs deposited at various electro-deposition potentials in molten carbonates fused at $450{ }^{\circ} \mathrm{C}$ or $540{ }^{\circ} \mathrm{C}$; these $\mathrm{CNPs}$ being washed and thereafter vacuum heat-treated at $600{ }^{\circ} \mathrm{C}$ before fluorination treatments.

\section{Synthesis procedures and characterization techniques}

\subsection{Synthesis and characteristics of starting carbon nano-powders (CNPs)}

CNPs have been firstly prepared using the same procedure as that described in detail elsewhere [29]. The carbon nano-powders (CNP) were prepared by electro-reduction of fused $\mathrm{Li}_{2} \mathrm{CO}_{3}-\mathrm{Na}_{2} \mathrm{CO}_{3}-\mathrm{K}_{2} \mathrm{CO}_{3}$ [30-36] with the eutectic composition (43.5/31.5/25 mol \%). Briefly, the carbonate powders (provided by VWR) were melted in a vitreous carbon crucible (Le Carbone Lorraine, France) placed in a cell made of an outer stainless steel envelope (amount of salt $\approx 180 \mathrm{~g}$ ). The constituents were dried under vacuum at $150{ }^{\circ} \mathrm{C}$ during $15 \mathrm{~h}$ to remove traces of water and then heat-treated very slowly up to the required temperature atmosphere. The electrochemical measurements were performed under $\mathrm{CO}_{2}$ atmosphere $\left(\mathrm{p}\left(\mathrm{CO}_{2}\right)=1 \mathrm{~atm}\right)$ to prevent the melt decomposition. The temperature of the molten salt was controlled with a chromel-alumel thermocouple. The working and the counter electrodes were a nickel sheet $\left(\approx 15 \mathrm{~cm}^{2}\right)$ and a graphite rod. The reference electrode was constituted of a silver wire placed in an alumina tube containing molten $\mathrm{Li}_{2} \mathrm{CO}_{3}-\mathrm{Na}_{2} \mathrm{CO}_{3}-\mathrm{K}_{2} \mathrm{CO}_{3}$ in the presence of $\mathrm{Ag}_{2}\left(\mathrm{SO}_{4}\right)\left(0.1 \mathrm{~mol} \mathrm{~kg}{ }^{-1}\right)$ [37]: the $\mathrm{Ag}^{+} / \mathrm{Ag}^{0}$ redox couple involved in the reaction was used as reference hereafter.

The electrodeposition of carbon powder CNPs was performed in a potentiostatic mode by applying a constant anode (graphite) - cathode (nickel) potential. After deposition, the Ni electrode was immersed into distilled water to disintegrate the hard-grey carbon deposit, which contains a large amount of solidified salt. Then $\mathrm{HCl}$ solution was introduced to remove carbonates from the powders. After washing, the CNPs were filtrated to obtain very fine and "quasi-spherical" particles. Finally, the powders were collected and dried at $600{ }^{\circ} \mathrm{C}$ under vacuum before physico-chemical analysis and testing in a Li primary battery. The deposition potentials and drying temperatures were chosen since they allow to obtain carbon powders with the highest specific surface area as shown recently $[35,36]$. The three studied pristine samples, noted A, B, and $\mathrm{C}$, were obtained by reduction of carbonates in the following conditions:

A: Raw CNP deposited at $-3 \mathrm{~V}$ in molten carbonates at $450{ }^{\circ} \mathrm{C}$, rinsed, dried at $600{ }^{\circ} \mathrm{C}$

B: Raw CNP deposited at $-3 \mathrm{~V}$ in molten carbonates at $540{ }^{\circ} \mathrm{C}$, rinsed, dried at $600{ }^{\circ} \mathrm{C}$

$\mathrm{C}$ : Raw CNP deposited at $-4 \mathrm{~V}$ in molten carbonates at $450{ }^{\circ} \mathrm{C}$, rinsed, dried at $600{ }^{\circ} \mathrm{C}$. 
Raman spectroscopy is a powerful tool to analyses the crystallinity and the degree of disorder of carbonaceous materials [38]. Because the penetration depth of the excitation laser beam for carbon is approximately $30 \mathrm{~nm}$, this technique probes mainly the surface of CNP particles. Raman spectra of samples A, B, and C depicted in Fig. 1 display a set of two broad peaks at ca. 1590 and $1370 \mathrm{~cm}^{-1}$ that are the characteristic G- and D-bands of carbon. The structure of the G-band is associated with the optically allowed $E_{2 \mathrm{~g}}$ zone-center mode of crystalline graphite, while the D-band is associated with the disorderallowed zone-edge modes of graphite [39]. The intensity ratio of these bands $\left(\mathrm{I}_{\mathrm{D}} / \mathrm{I}_{\mathrm{G}}\right)$ defines the degree of defects within the $\mathrm{CF}_{\mathrm{x}}$. The Raman spectrum of sample C (Fig. 1) displays a well-resolved G-band and the lowest $\mathrm{I}_{\mathrm{D}} / \mathrm{I}_{\mathrm{G}}$ ratio, which match well with the XRD patterns showing a better crystallinity and a decrease in defect concentration compared with those of samples A and B. In the following, these two latter types of pristine CNP will be more investigated because their reactivity should be more important.

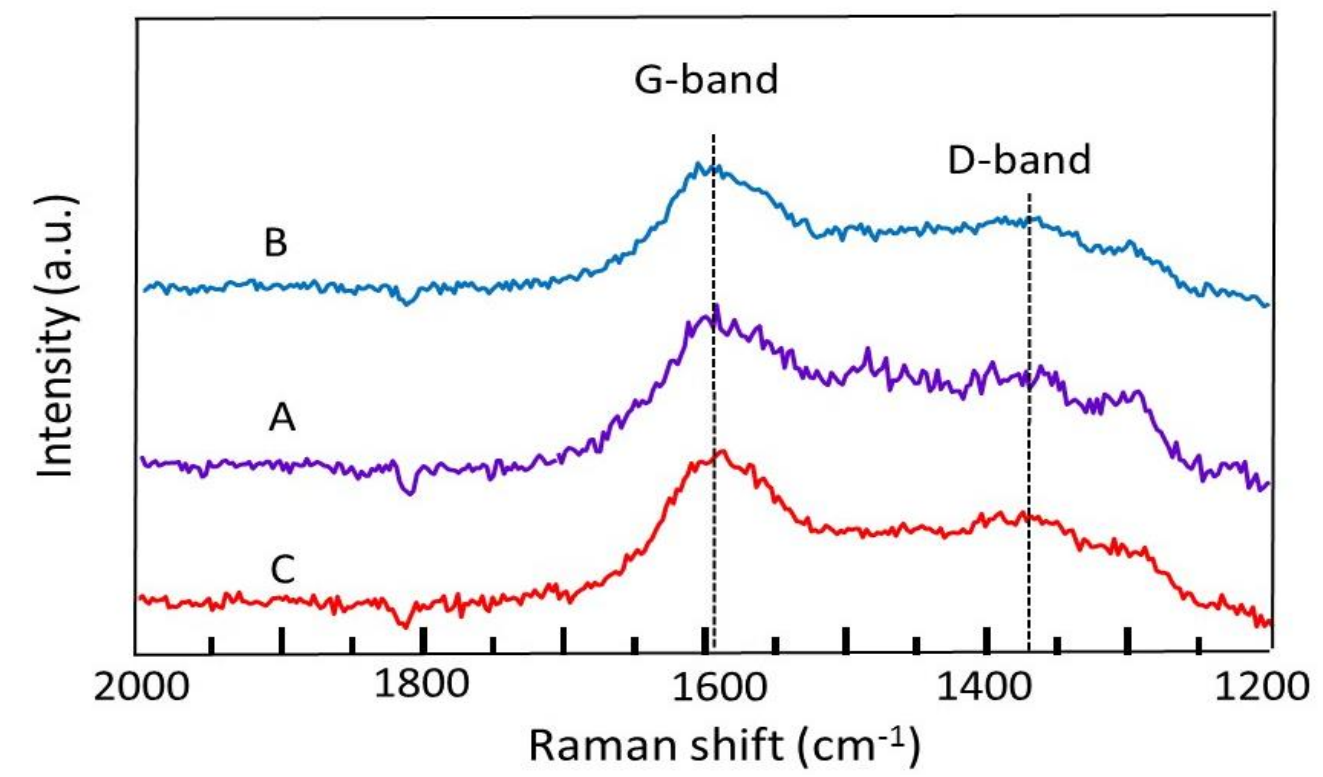

Fig.1. Raman spectra of CNPs samples A, B, and C.

In order to emphasize that, whatever the final heat treatment, the carbonaceous powder was composed of nanosized particles, SEM and TEM images of $3000{ }^{\circ} \mathrm{C}$-treated CNPs are reported in Fig. 2. The average size of the particles is below $100 \mathrm{~nm}$ with a narrow size distribution. Moreover, the carbonaceous materials exhibit a wide range of morphologies, from turbostratic to amorphous domains, together with the presence of graphene evidenced on the TEM images. 

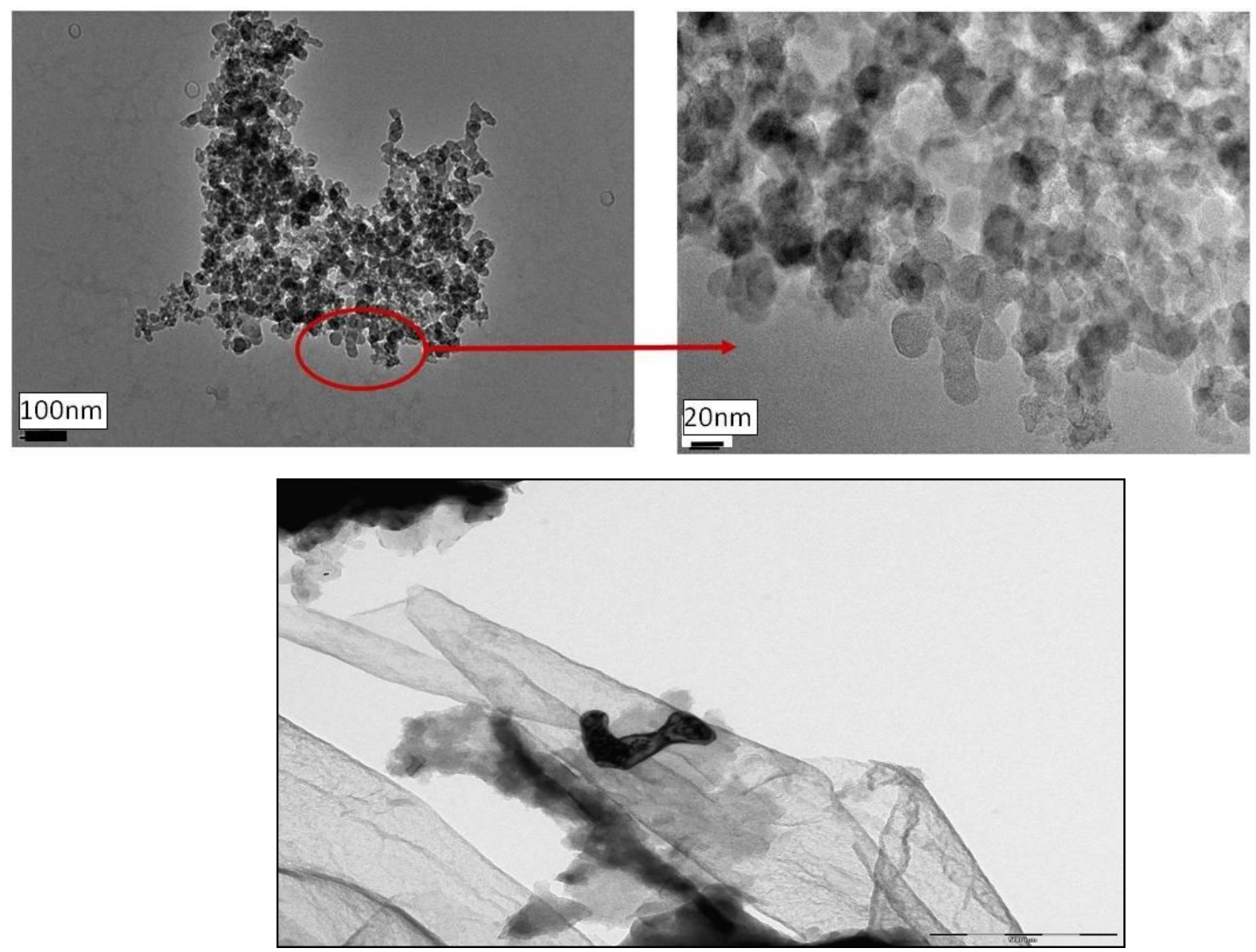

Fig. 2. TEM images of nano-sized $3000^{\circ} \mathrm{C}$-heat-treated CNPs (upper images), with the occurrence of graphene particles (lower image)

\subsection{Synthesis of fluorinated carbon nano-powders (F-CNPs)}

Concerning the fluorination procedure, it is well-established that graphite can react with fluorine gas at temperatures below $100{ }^{\circ} \mathrm{C}$ in the presence of a catalyst such as $\mathrm{HF}$. The resulting products are called fluoride graphite intercalation compounds denoted F-GICs (semi-ionic C-F bonds) or graphite fluorides (covalent C-F bonds), depending on the experimental conditions [6,40]. Such compounds have higher voltage but usually lower capacity than those obtained with $\mathrm{CF}_{\mathrm{x}}$ when they are used as positive materials in primary lithium batteries [41]. F-GICs have higher electrical conductivity compared to $\mathrm{CF}_{\mathrm{x}}$ due to the presence of the semi-ionic C-F bonding and charge transfer between the intercalated electron-acceptor species and the graphene layers. This leads to very high conductivity that can exceed $10^{5} \mathrm{~S} \cdot \mathrm{cm}^{-1}$, whereas the conductivities of CF carbon fluoride range about $10^{-14} \mathrm{~S} \cdot \mathrm{cm}^{-1}$ due to covalent $\mathrm{C}-\mathrm{F}$ bonds. In the present work, CNPs prepared in molten carbonates have been fluorinated in pure or diluted $\mathrm{F}_{2}$, whereby the pristine CNPs were obtained at various electro-deposition potentials in molten carbonates fused at 450 and $540{ }^{\circ} \mathrm{C}$, and heat-treated at $600{ }^{\circ} \mathrm{C}$ after washing under vacuum. In order to avoid evolution of gaseous phases $\left(\mathrm{CF}_{4}\right)$, most of fluorination experiments on pristine carbon nanoparticles were performed at room temperature in 
a nickel reactor with $\mathrm{F}_{2}$ (purity: 99.4-99.7\%), generally with $\mathrm{F}_{2} 50 \%$ diluted in Ar for $24 \mathrm{~h}$. However, the influence of $\mathrm{F}_{2}$ concentrations and reaction temperatures was also studied (see Table 1, Figs. 6 and 8)

\subsection{Physical-chemical characterization techniques}

X-ray diffraction (XRD) measurements were performed with a Rigaku Ultima III X-Ray diffractometer with a CuKa radiation $\left(\lambda_{1}=1.540598 \AA\right)$. The values of $d_{002}$ and $L_{\mathrm{c}}$ deduced from XRD analysis were estimated with an error of 5\%. Transmission electron micrographs were obtained with a JEOL JEM 100 CX II transmission electron microscope equipped with a JEOL high resolution scanning attachment (STEM-SEM ASID 4D). Scanning electron microscopy images were obtained with a JEOL JEM 100 CX II scanning electron microscope equipped with a JEOL high resolution scanning attachment (SEM-FEG).

Surface characterizations were done by XPS measurements using a VG 220 i-XL ESCALAB spectrometer under ultrahigh vacuum conditions. The radiation was an Al monochromatized source (1486.6 $\mathrm{eV})$. Silver $\mathrm{Ag} 3 \mathrm{~d}_{5 / 3}$ at the binding energy $B E=368.2 \mathrm{eV}$ was chosen for the calibration of the spectrometer. All the spectra were referenced to $\mathrm{C} 1 \mathrm{~s}$ located at binding energy (BE) of $284.8 \mathrm{eV}$. Survey and high resolution spectra were recorded, then fitted with an Avantage processing program provided by ThermoElectron. Each C1s, O1s, and F1s component was considered as having similar full-width-at-half-maximum $(\mathrm{FWHM}=1.5 \mathrm{eV})$ for all samples. Raman spectra were collected with a LabRAM spectrometer controlled by LabSpec 5 (Horiba Jobin Yvon) equipped with a laser wavelength of $514.5 \mathrm{~nm}$ at low power excitation $(<1 \mathrm{~mW})$. The spectrometer was first calibrated with Si standard, then the data were recorded with scanning time 1-5 min.

\subsection{Electrochemical tests}

The F-CNPs tested as cathode materials in lithium batteries were prepared by mixing the active carbonaceous material (90 wt.\%) with graphite (5 wt.\%) as conductive additive and polytetrafluoroethylene (PTFE) dried powders (5 wt.\%) in a very dry atmosphere. After a drying step of the PTFE binder above $80{ }^{\circ} \mathrm{C}$, the resulting black paste was then deposited onto a grid and dried at $60-80{ }^{\circ} \mathrm{C}$ under vacuum to avoid residual moisture and to partially evaporate the solvent. The electrochemical performances of the prepared F-CNPs-based electrodes as cathode materials in a rechargeable lithium battery was studied in 1 $\mathrm{mol} \cdot \mathrm{L}^{-1} \mathrm{LiPF}_{6}$-EC:DMC (1:1) solution (LP30, Merck) at room temperature in a glove box (water content $\leq$ $5 \mathrm{ppm}$ ) under argon atmosphere. The counter and reference electrodes were metallic lithium foils. All potential values will be referred to this $\mathrm{Li} / \mathrm{Li}^{+}$reference. The galvanostatic charge-discharge curves were performed using a potentiostat/galvanostat (VMP3 Bio-Logic) in the potential range of 1-4 V. 


\section{Physicochemical and electrochemical properties of F-CNPs}

3.1. Morphological and structural characteristics

After fluorination, elemental analyses of CNPs were carried out by EDX measurements. In Fig. 3 the inserted Table lists the weight percentage of C and F for different fluorinated A-, B-, and C-type samples. The compound is indeed formed of these two elements, but the presence of oxygen is attested by its K-line around $0.5 \mathrm{keV}$, and will be more definitively characterized by XPS (see Table 1). Brunauer-EmmettTeller (BET) results show that the CNPs prepared in low-temperature conditions exhibit high specific surface areas varying from $80 \mathrm{~m}^{2} \cdot \mathrm{g}^{-1}$ to about $1300 \mathrm{~m}^{2} \cdot \mathrm{g}^{-1}$, depending on the experimental electro-deposition conditions, notably the temperature of molten carbonates.

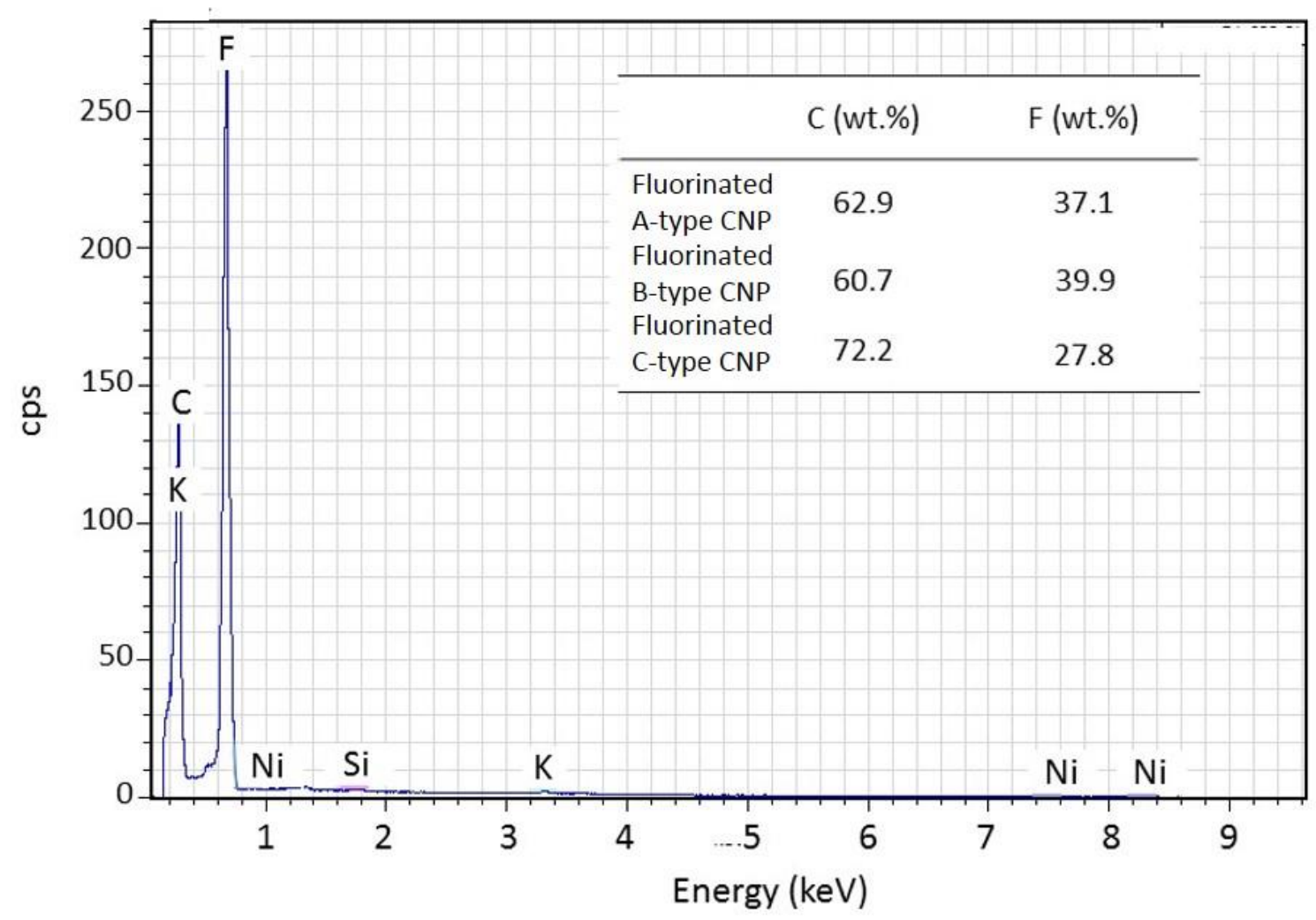

Fig. 3. EDX spectrum of CNP A-sample heat-treated at $600{ }^{\circ} \mathrm{C}$ and fluorinated with $50 \%$ diluted $\mathrm{F}_{2}$ at room temperature. The inserted table lists the elemental analysis of the different types of pristine-CNPs, fluorinated in similar conditions.

As explained above, mild fluorination conditions: i.e., diluted $\mathrm{F}_{2}$ and temperatures below $100{ }^{\circ} \mathrm{C}$, have allowed to maintain the nano-morphology of F-CNPs, as illustrated in Fig. 4. 


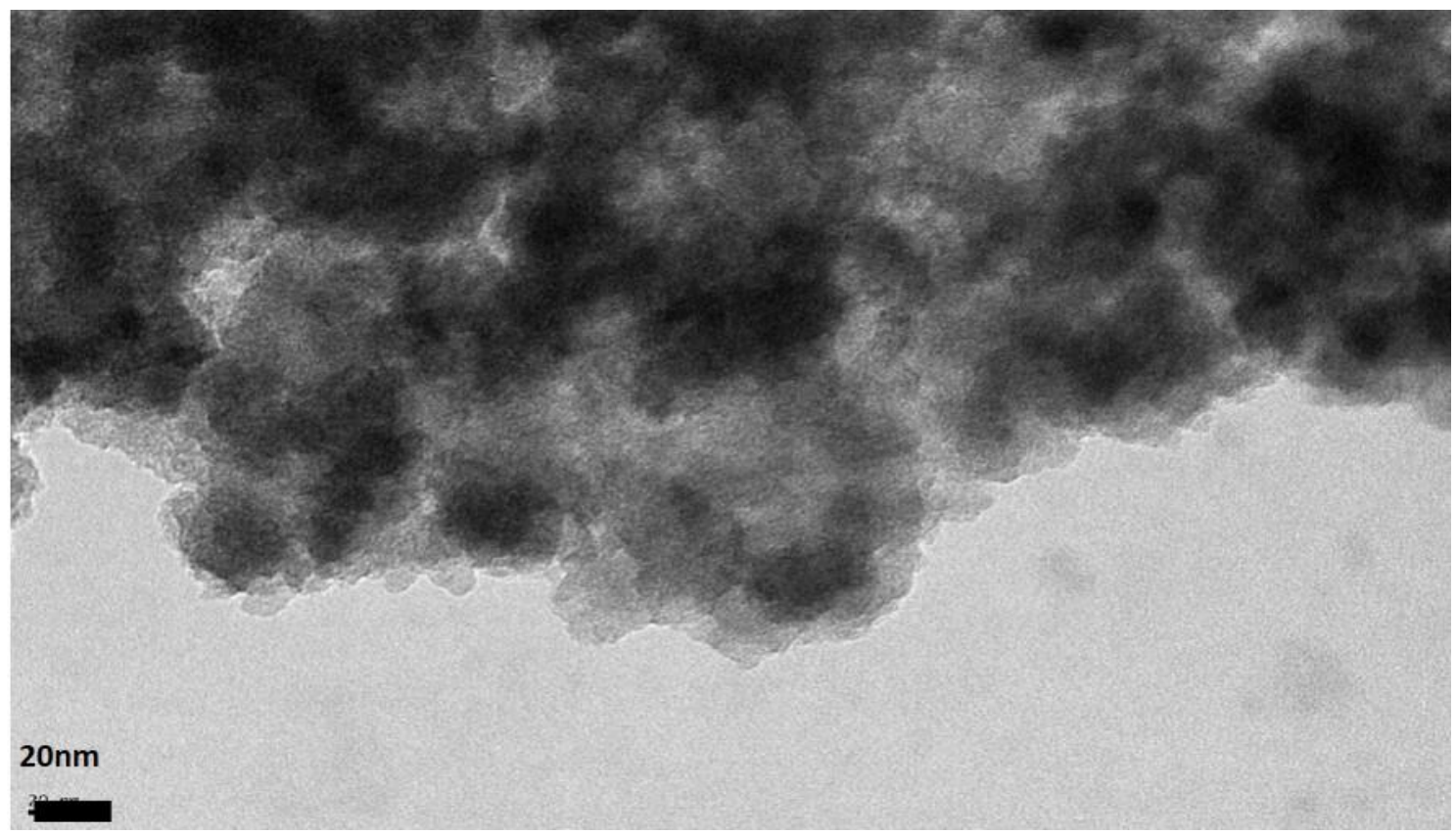

Fig. 4. TEM image of fluorinated $\left(\mathrm{F}_{2} 50 \%\right.$, RT) CNP (pristine A-sample), clearly showing that the nanostructure of CNPs is preserved after fluorination.

It is well-known that carbon and fluorine have a strong reactivity even at room temperature (RT) generally in the presence of a catalyst (such as HF). The XRD characteristics of CNPs strongly depend on the deposition conditions of molten carbonates and on the washing procedure as shown in Fig. 5. However, whatever the starting materials, it was observed that the fluorination of CNPs using pure fluorine gas is somewhat difficult to control and gives rise to a highly exothermic reaction with the evolution of gaseous $\mathrm{CF}_{4}$. The amount of remaining solid product at the end of the reaction is very small. Such reactivity could be explained by the presence of very reactive $\mathrm{C}-\mathrm{O}, \mathrm{C}-\mathrm{OH}$ bonds onto the surface, as will be discussed hereafter in the XPS session. Thus, a dilution of $\mathrm{F}_{2}$ into a neutral gas such as Ar has been generally preferred. 


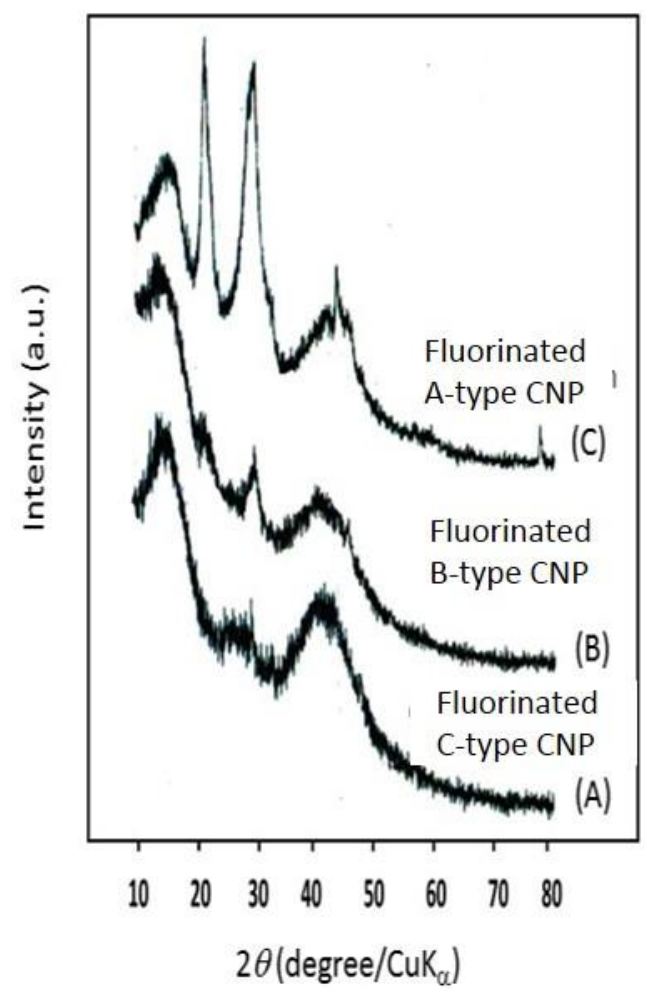

Fig. 5. XRD patterns of F-CNP powders prepared by fluorination of various pristine samples at room temperature for $24 \mathrm{~h}$ under $50 \% \mathrm{~F}_{2}$.

Fig. 6 gives the XRD patterns of a pristine sample-B-type taken as an example- and those of samples fluorinated at room temperature with different percentage of $F_{2}$ in the $F_{2}$ :Ar gas mixture, that is from 10 to $100 \%$. In the pristine sample, the peak at about $26.4^{\circ}$ before fluorination is attributed to the (002) diffraction line of graphitized carbon as previously reported [29]. The F-CNPs exhibit different crystallinities and morphologies depending on the experimental fluorination conditions. As shown in Fig.6, the intensity of the (002) diffraction line decreases and its FWHM becomes wider as soon as fluorination is carried out (10\% $\mathrm{F}_{2}$ at RT for $2 \mathrm{~h}$ ), indicating a loss of crystallinity. For higher $\mathrm{F}_{2}$ contents in the gas mixture, new peaks relative to the formation of carbon-fluorine compounds are observed. For $50 \% \mathrm{~F}_{2}$, the XRD pattern can be interpreted as a mixture of graphite fluoride $\mathrm{C}_{2} \mathrm{~F}$ and $\mathrm{GIC}\left(\mathrm{CF}_{\mathrm{x}}\right)$. When pure fluorine $\left(100 \% \mathrm{~F}_{2}\right)$ is used, a well-identified peak at $2 \theta \approx 18^{\circ}$ related to the (001) Bragg line of $\mathrm{C}_{2} \mathrm{~F}$ is evidenced. However, we have already mentioned that the use of $100 \% \mathrm{~F}_{2}$ to prepare F-CNPs is not suitable due to high reactivity of pure $\mathrm{F}_{2}$ with the pristine powders, the reaction leading to solid F-CNPs being difficult to control. However, the interplanar distance of $d_{001}=6.2 \AA$ matches well with values of the literature [41] and provides a strong evidence for the crystalline nature of the graphite fluoride generated by the used fluorination procedure.

For these reasons, only F-CNPs fluorinated in more reliable conditions, i.e. under $\mathrm{F}_{2} 50 \%$ diluted in Ar will be used in the electrochemical tests. 


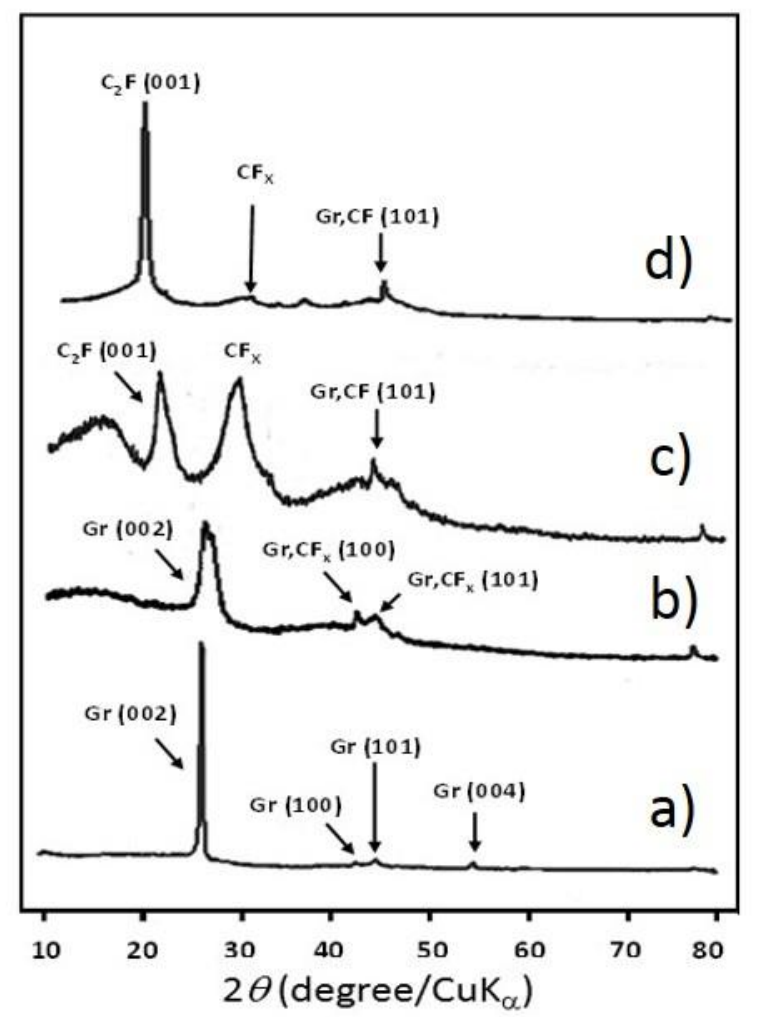

Fig. 6. Influence of the amount of $F_{2}$ in the Ar: $F_{2}$ mixture on the XRD patterns of F-CNP powders: a) pristine B-type CNP, b) fluorinated under $10 \% \mathrm{~F}_{2}$ at RT for $2 \mathrm{~h}, \mathrm{c}$ ) under $50 \% \mathrm{~F}_{2}$ at RT for $2 \mathrm{~h}$, and d) $100 \%$ $\mathrm{F}_{2}$ at RT for $2 \mathrm{~h}$.

\section{2. Nature of C-F bonds in F-CNPs from XPS investigation}

XPS measurements were carried out with F-CNPs prepared in various conditions to identify the electronic modifications induced by the fluorination procedure (samples A and B). The analysis of the chemical surface is important since the reactivity of the different types of carbon present in the material not only depends on the size of crystallites but also on the presence of residual oxygen (Table 1). The survey spectrum of a pristine A-type sample is shown in Fig.7a. It is in agreement with the presence of carbon and oxygen only. The oxygen content at the particle surface deduced from the survey spectrum analysis is larger before fluorination (about $16.8 \pm 0.4 \%$ ), due to the high reactivity of the nano-structured CNP sample and varied types of carbon particles. After fluorination at room temperature with $10 \%$ diluted $\mathrm{F}_{2}$ (Fig. $7 \mathrm{~b}$ ), the O1s contribution has almost disappeared (1.2 atom \%), whereas the F1s contribution is 46.2\%. For increasing fluorination temperatures (denoted $\mathrm{T}_{\mathrm{F} 2}$ ) and amounts of $\mathrm{F}_{2}$ in the gas mixture, the oxygen content decreases significantly due to the fluorination of the $\mathrm{C}-\mathrm{O}$ bonds; in parallel, an increase of the $\mathrm{F}$ concentration is pointed out. Traces of oxygen are still detected on the surface of CNPs, even after the fluorination procedure and whatever the fluorination conditions. One cannot exclude that the fluorination of the CNPs leads also to the formation of small amount of graphite oxyfluorides. EDX analyses of the bulk 
product reveals mainly the presence of $\mathrm{C}$ and $\mathrm{F}$ with sometimes the presence of a trace of oxygen (about $2 \%)$.
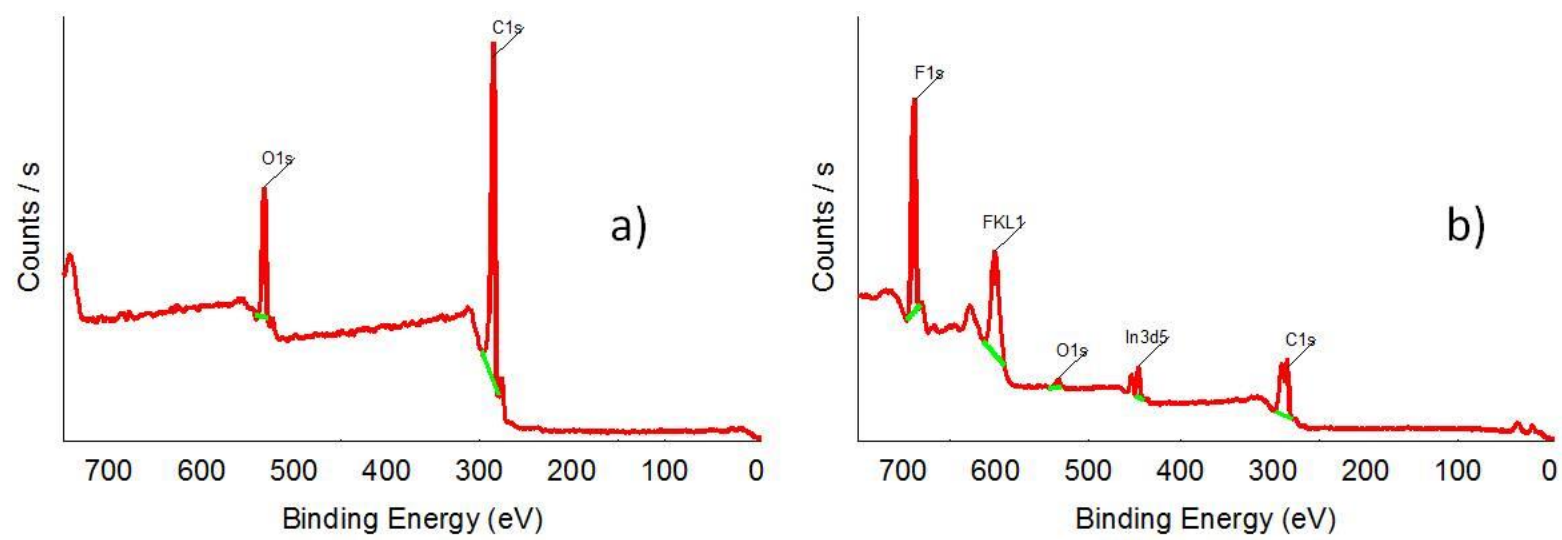

Fig. 7. Survey XPS spectra of a) A-type pristine CNP sample and b) A-sample fluorinated under $10 \%$ diluted $\mathrm{F}_{2}$ at $\mathrm{RT}$.

Table 1. Elemental composition (atom \%) of fluorinated carbon deduced from analysis of XPS spectra.

\begin{tabular}{c|ccccc}
\hline $\begin{array}{c}\text { Pristine CNP } \\
\text { samples }\end{array}$ & $\mathrm{F}_{2}(\%)$ & $\mathrm{T}_{\mathrm{F} 2}\left({ }^{\circ} \mathrm{C}\right)$ & $\mathrm{C}(\%)$ & $\mathrm{F}(\%)$ & $\mathrm{O}(\%)$ \\
\hline \multirow{5}{*}{ A-type } & - & - & 83.6 & - & 16.4 \\
\cline { 2 - 6 } & 10 & $\mathrm{RT}$ & 50.5 & 37.4 & 11.5 \\
\cline { 2 - 6 } & 10 & 100 & 44.4 & 49.9 & 5.7 \\
\cline { 2 - 6 } & 100 & $\mathrm{RT}$ & 52.1 & 46.4 & 1.5 \\
\cline { 2 - 6 } & 100 & 100 & 33.8 & 65.5 & 0.7 \\
\hline \multirow{3}{*}{ B-type } & - & - & 82.8 & - & 17.2 \\
\cline { 2 - 6 } & 10 & $\mathrm{RT}$ & 51.4 & 37.5 & 11.1 \\
\cline { 2 - 6 } & 10 & 100 & 48.0 & 37.5 & 6.5 \\
\hline
\end{tabular}

It can be noted that the amount of $\mathrm{F}_{2}$ gas in the $\mathrm{Ar}: \mathrm{F}_{2}$ mixture seems to be a more decisive factor than the fluorination temperature on the global amount of fluorine. Although the highest fluorine level in F-CNP is observed using pure $\mathrm{F}_{2}$ fluorine at $100{ }^{\circ} \mathrm{C}(\mathrm{F} 1 \mathrm{~s}: 65.6 \%)$, the uncontrolled reaction mechanism avoids the use of such a sample in the following. Only a very small amount of fluorinated product remains indeed in the reaction boat after the reaction. 

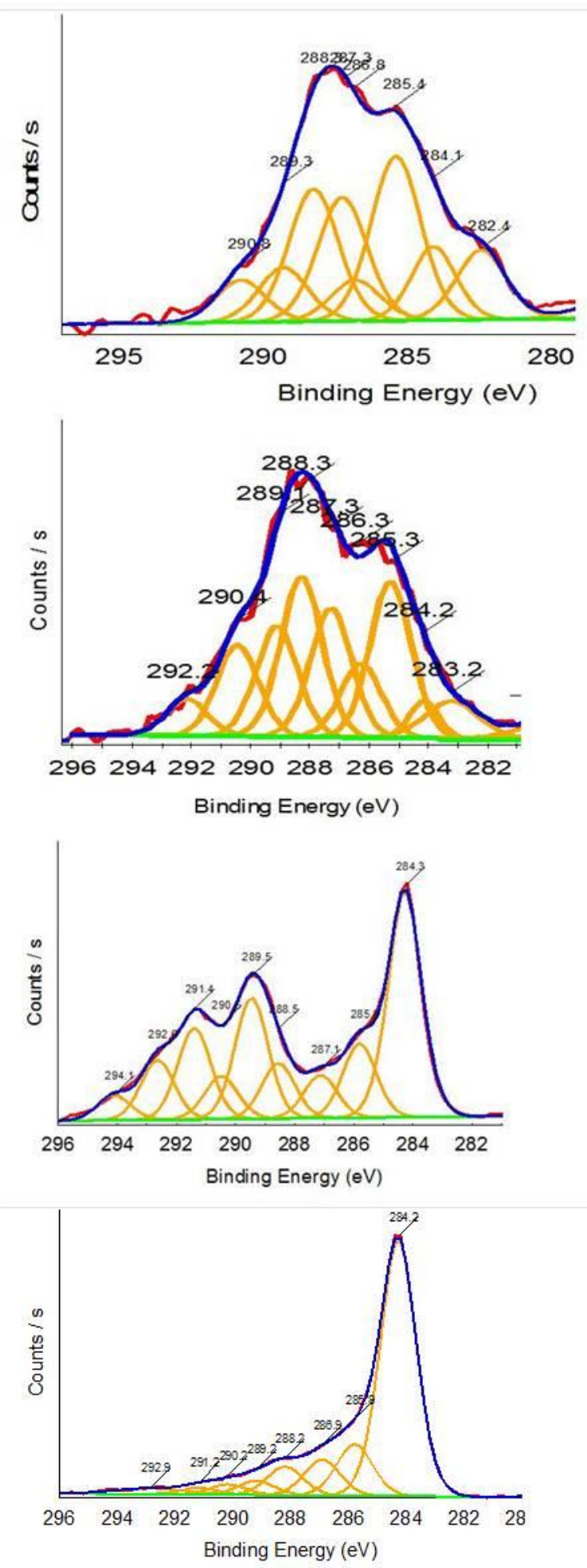

C)

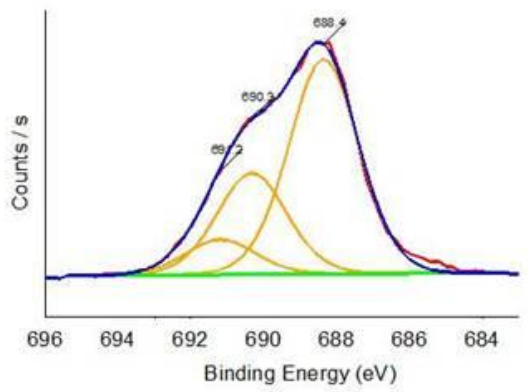

b)

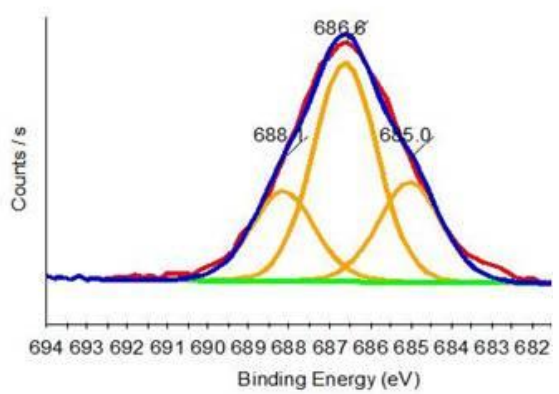

a)

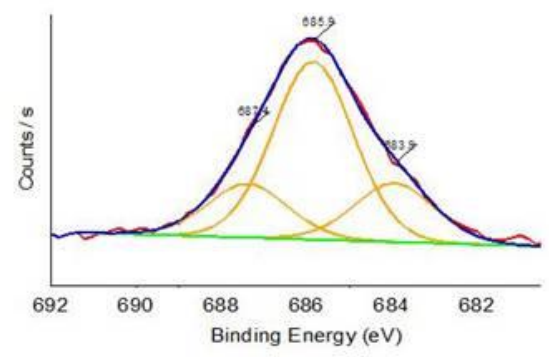

Fig. 8. Comparison of the XPS C1s (left) and F1s (right) components vs. the fluorination conditions: a) $10 \%$ $\mathrm{F}_{2}$ at $\left.\mathrm{RT}, \mathrm{b}\right) 100 \% \mathrm{~F}_{2}$ at $\mathrm{RT}$, and c) $10 \% \mathrm{~F}_{2}$ at $100{ }^{\circ} \mathrm{C}$, carried out on a pristine A-type $\mathrm{CNP}$ for which the C1s spectrum is shown at the bottom. 
The effect on the XPS C1s and F1s spectra of the amount of $\mathrm{F}_{2}$ in the gas mixture $(10 \%$ and $100 \%$ $\left.\mathrm{F}_{2}\right)$ and of the reaction temperature $\left(25\right.$ and $\left.100{ }^{\circ} \mathrm{C}\right)$ is shown in Fig. 8. After fluorination with $10 \% \mathrm{~F}_{2}-\mathrm{RT}$, the XPS C1s envelope exhibits two maxima at higher binding energy values (> $290 \mathrm{eV}$ ), in addition to the peak of the starting $\mathrm{C} 1 \mathrm{~s}$ at around $284 \mathrm{eV}$. These multiple components at higher BE can be attributed to carbon atoms surrounded by an increasing number of $\mathrm{F}$ atoms (in particular $-\mathrm{CF}_{2}$ and $-\mathrm{CF}_{3}$ groups). These high BE peaks become predominant when increasing the fluorination temperature from 25 to $100{ }^{\circ} \mathrm{C}$ (Fig. 8c) and for increasing $\mathrm{F}_{2}$ contents from 10 to $100 \%$ (Fig. 8b). Such a trend is also observed in the F1s spectra. For $10 \% \mathrm{~F}_{2}$ - RT fluorination (Fig. 8a), the envelope can be fit into three components at around 684, 686, and $687.4 \mathrm{eV}$ that take into account the different types of C-F bonding, i.e. semi-covalent and covalent ones. For increasing fluorine contents at $\mathrm{T}_{\mathrm{F} 2}=25{ }^{\circ} \mathrm{C}$ (Fig. 8b), there is a small shift of the F1s components towards higher BE with components occurring at 685, 686.6, and $688.1 \mathrm{eV}$, whereas for a fluorination experiment at $\mathrm{T}_{\mathrm{F} 2}=100{ }^{\circ} \mathrm{C}$ (Fig. 8c), the maximum of the envelope is shifted to $688.4 \mathrm{eV}$, with the two other components at even higher BE: 690.3 and $691.2 \mathrm{eV}$. This should mean that only covalent F$\mathrm{C}$ bonds are found with different types of $\mathrm{F}$ environment, whatever the different types of carbon particles $[42,43]$.

The C1s spectrum of pristine A-sample (as shown at the bottom of Fig. 8) exhibits a predominant component with a binding energy of $284.2 \mathrm{eV}(\mathrm{FWHM}=1.54 \mathrm{eV})$, which is the fingerprint of $\mathrm{sp}^{2}$ hybridization. In addition, this peak presents a tail toward the high binding energies, which can be fit by a series of six peaks with weak intensity. These are attributed to a small amount of $\mathrm{sp}^{3}$ species in the CNPs. Upon light fluorination, the $\mathrm{C} 1 \mathrm{~s}$ photoelectron spectrum (Fig. 8a) presents a more complex envelop, which can be decomposed in nine symmetrical Gaussian peaks denoted $\mathrm{C}_{1}$ to $\mathrm{C}_{9}$ and assigned in Table 2 . Three XPS components exist at binding energies of ca. 291.4, 292.6, and $294.1 \mathrm{eV}$ that can be due to the $\mathrm{sp}^{3}$ hybridization associated with the $-\mathrm{CF}_{2}-\mathrm{CF}_{2-},-\mathrm{CF}_{2}-\mathrm{CF}_{3}$ and $\mathrm{CF}_{3}$ groups in a very fluorinated environment, respectively [40]. A small contribution due to semi-ionic C-F bonds at $288.5 \mathrm{eV}$ has been taken into account as well. The contributions above $285 \mathrm{eV}$ are more and more important (see Fig. 8b, c) with increasing either $\mathrm{T}_{\mathrm{F} 2}$ or the $\mathrm{F}_{2}$ concentration, with a maximum peak of the $\mathrm{C} 1 \mathrm{~s}$ envelope at around $288 \mathrm{eV}$. This trend is in agreement with increased formation of C-F covalent bonds. 
Table 2. XPS data deduced from the fitting of C1s photoelectron peak of A-type CNP fluorinated at room temperature (see Fig. 8a).

\begin{tabular}{|c|c|c|c|}
\hline Peaks & $\mathrm{BE}(\mathrm{eV})$ & $\mathrm{I}_{\mathrm{i}}($ atom $\%)$ & Assignment \\
\hline $\mathrm{C}_{1}$ & 284.3 & 30.4 & $\mathrm{C}-\mathrm{C}$ \\
\hline $\mathrm{C}_{2}$ & 285.8 & 10.2 & $\mathrm{C}-\mathrm{CO}$ and/or $\mathrm{C}-\left(\mathrm{CH}_{2}-\mathrm{CF}_{\mathrm{x}}\right.$ \\
\hline $\mathrm{C}_{3}$ & 287.1 & 6.1 & $\mathrm{C}=\mathrm{O}$ and $/$ or $\mathrm{CH}_{2}-\mathrm{CF}_{2}$ \\
\hline $\mathrm{C}_{4}$ & 288.5 & 7.7 & $\begin{array}{l}\mathrm{CHF}^{-\mathrm{CH}_{2}} \text { and } \mathrm{CHF}-\mathrm{CHF} ; \text { semi-ionic } \mathrm{C}-\mathrm{F} \text { bond } \\
\text { (intercalation) }\end{array}$ \\
\hline $\mathrm{C}_{5}$ & 289.5 & 16.5 & $\mathrm{CHF}-\mathrm{CF}_{2}$ and $\mathrm{CF}_{\mathrm{x}}-\mathrm{CF}-\mathrm{CF}_{\mathrm{x}}$, with $\left(\mathrm{x}, \mathrm{x}^{\prime}=2,3\right)$ \\
\hline $\mathrm{C}_{6}$ & 290.5 & 5.6 & $\mathrm{CF}_{2}-\mathrm{CH}_{2}, \mathrm{CF}$ groups of first neighbors of $\mathrm{CF}_{n}$ groups \\
\hline $\mathrm{C}_{7}$ & 291.4 & 12.5 & $-\mathrm{CF}_{2}-\mathrm{CF}_{2}-$ \\
\hline $\mathrm{C}_{8}$ & 292.6 & 8.0 & $-\mathrm{CF}_{2}-\mathrm{CF}_{3}$ \\
\hline $\mathrm{C}_{9}$ & 294.1 & 3.0 & $\mathrm{CF}_{3}$ groups in a highly fluorinated environment \\
\hline
\end{tabular}

\section{3. Electrochemical features of F-CNPs as positive electrode in a primary lithium battery}

In this section, we investigate the electrochemical performances of F-CNPs as positive electrodes in primary lithium batteries. As previously quoted, the same procedure was used: the samples were rinsed, then heat-treated at $600{ }^{\circ} \mathrm{C}$, and finally fluorinated. Whatever the samples and the fluorination procedure, the chronopotentiograms exhibit always the same shape (Fig. 9): a small plateau is observed at around $3 \mathrm{~V}$ $v s$. $\mathrm{Li}^{+} / \mathrm{Li}^{0}$, followed by a continuous decrease of the potential vs. time without the occurrence of a welldefined and flat plateau usually observed in the case of commercial $\mathrm{CF}_{\mathrm{x}}$ compounds [44-47]. The shape of the chronopotentiograms can probably be related to a non-homogeneous fluorination of the F-CNPs. This is due to the high reactivity of the CNPs with fluorine as discussed above and the difficulties to control the reaction. As a result, a reproducible product may be difficult to obtain for commercial production.

Fluorine-CNPs were tested in the presence of $1 \mathrm{~mol} \cdot \mathrm{L}^{-1} \mathrm{LiClO}_{4}$-propylene carbonate (PC) as electrolyte, and their electrochemical performances have been compared with commercial $\mathrm{CF}_{\mathrm{x}}$. Typical discharge curves obtained at a discharge rate of $18.5 \mathrm{~mA} \cdot \mathrm{g}^{-1}$ for pristine A-, B-, and C-CNPs fluorinated at room temperature using a gas mixture containing $50 \%$ of $\mathrm{F}_{2}$ during $24 \mathrm{~h}$ are given in Fig. 9. Whatever the samples and the fluorination process, the chronopotentiograms exhibit always the same shape: a small plateau is observed at around $3 \mathrm{~V} v s . \mathrm{Li}^{+} / \mathrm{Li}^{0}$, followed by a continuous decrease of the potential $v s$. time without any occurrence of a well-defined and flat plateau, which is usually observed in the case of commercial $\mathrm{CF}_{\mathrm{x}}$ compounds. The shape of the chronopotentiograms is probably due to a non-homogeneous fluorination of 
the F-CNPs. This is attributed to the high reactivity of the CNPs with fluorine as discussed above and the difficulties to control the reaction of fluorination.

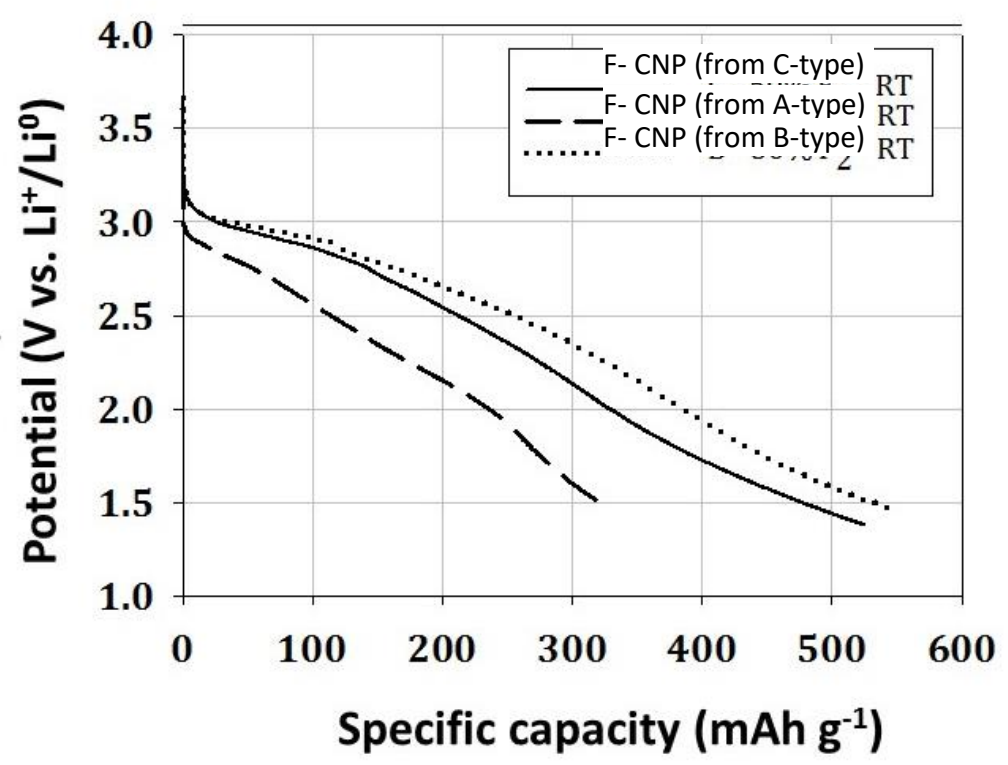

If pristine A-, B-, and C-CNPs at room temperature using a gas mixture containing $50 \%$ of $\mathrm{F}_{2}$ during $24 \mathrm{~h}$. Rate: $18.5 \mathrm{~mA} \cdot \mathrm{g}^{-1}$.

Two additional observations must be underscored whatever the sample. First, the open-circuit voltage (OCV) is close to $3.80 \mathrm{~V} v s . \mathrm{Li}^{+} / \mathrm{Li}^{0}$, a value much higher than the classical one observed with commercial graphite fluorides. It can be explained by the presence of non-fluorinated domains as revealed by XRD and XPS measurements and the presence of semi-ionic C-F bonds, which render the sample more conducting than insulating $\mathrm{CF}_{\mathrm{x}}$. Second, due to the conductive properties of the $\mathrm{CF}_{\mathrm{x}}$ materials, the chronopotentiograms of the F-CNPs do not evidence potential delay at the beginning of the discharge curves. In other words, even if the fluorine content in the sample is low, F-CNPs can support higher discharge rates compared to commercial $\mathrm{CF}_{\mathrm{x}}$, as clearly shown in Figs. $10 \mathrm{a}, \mathrm{b}$. In these data, the behavior of nano-F-CNPs from B-type CNPs fluorinated with $50 \%$ of $\mathrm{F}_{2}$ during $24 \mathrm{~h}$ and with approximate $\mathrm{CF} \sim 0.43$ formula is compared with commercial $\mathrm{CF}_{\mathrm{x}}$ at $\mathrm{C} / 5$ and $1 \mathrm{C}$ rates. The behavior of nano-F-CNPs $(\mathrm{CF} \sim 0.43)$ at various discharge rates: $1 \mathrm{C}, \mathrm{C} / 10$, and $\mathrm{C} / 100$ is illustrated in Fig. 10c. 

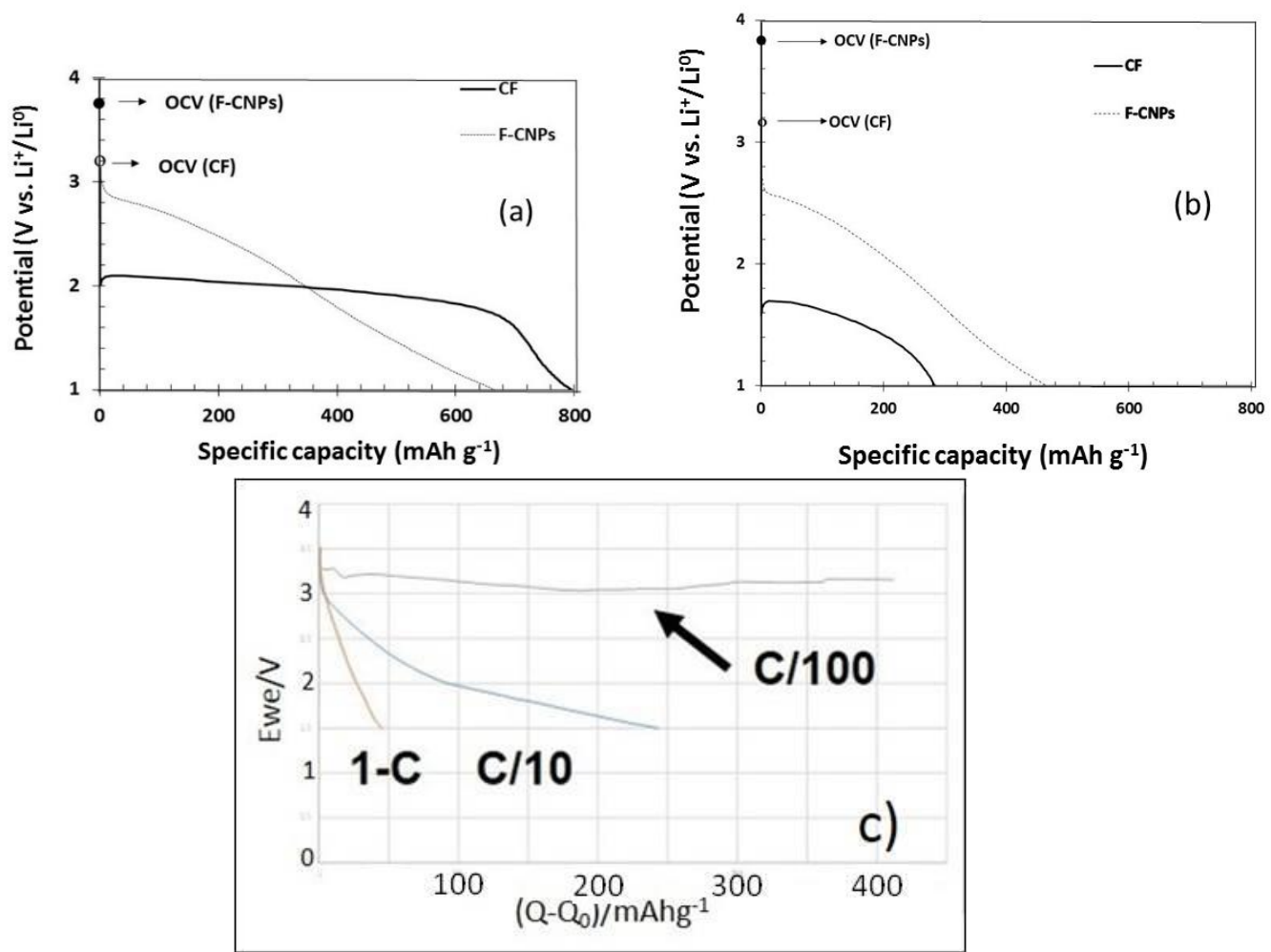

Fig. 10. Comparison of the discharge curves obtained with commercial $\mathrm{CF}_{\mathrm{x}}\left(\mathrm{CF} \sim_{0.65}\right)$ and $\mathrm{F}-\mathrm{CNP}\left(\mathrm{CF} \sim_{0.43}\right)$ at a) $\mathrm{C} / 5$ rate and b) $1 \mathrm{C}$ rate. Discharge curves of $\mathrm{F}-\mathrm{CNPs}$-based Li-battery at c) $1 \mathrm{C}, \mathrm{C} / 10$, and $\mathrm{C} / 100$ rates.

The difference in electrochemical performances observed for F-CNPS can be significantly noted for high discharge at $1 \mathrm{C}$ rate (Fig. 10b), for which the discharge potential is about 0.7-0.9 $\mathrm{V}$ higher than that obtained with commercial $\mathrm{CF}_{\mathrm{x}}$. The delivered capacity of CNPs is also slightly increased $\left(450 \mathrm{mAh} \cdot \mathrm{g}^{-1}\right)$ in comparison with that of $\mathrm{CF}_{\mathrm{x}}$ compounds.

\section{Concluding remarks}

In this work, we have shown that carbon nanoparticles can be produced by direct electrochemical reduction of molten Li-Na-K carbonates at the eutectic composition (43.5/31.5/25 mol \%). The obtained CNPs are composed of both amorphous and graphitized domains, as revealed by XRD, with a low crystallinity. XPS investigations have pointed out the presence of different types of C-O bonds. The CNPs prepared in our experimental conditions exhibit high specific surface area which can vary from about $80 \mathrm{~m}^{2} \mathrm{~g}^{-1}$ to about $1300 \mathrm{~m}^{2} \mathrm{~g}^{-1}$ depending on the experimental electrodeposition conditions notably the temperature of molten carbonates. The CNPs are characterized by the presence of ultra- and super-microporosity, meso- and macroporosity. The carbon powders were tested in electrochemical capacitors as negative electrode in 
presence of aqueous electrolyte. Capacitance values of $135 \mathrm{~F} \cdot \mathrm{g}^{-1}$ for single electrode measurement have been determined in aqueous $0.5 \mathrm{~mol} \cdot \mathrm{L}^{-1} \mathrm{~K}_{2} \mathrm{SO}_{4}$. Thus, the CNP electrode could be considered as negative electrode of so-called hybrid carbon/ $\mathrm{MnO}_{2}$ cells; however, their limited potential window due to hydrogen evolution reaction occurring at higher potential than standard activated carbon material would hinder their applicability. These experiments revealed that CNP can be an interesting alternative to activated carbon for electrochemical capacitors applications. However, improvements have to be made in order to monitor surface functionalities. The fluorination of the CNPs has been performed using $\mathrm{F}_{2}$ gas. CNPs exhibit a very high reactivity $v s$. fluorine gas due to the nanostructure of the carbon materials and the presence of a large amount of $\mathrm{C}-\mathrm{O}$ bonding onto the surface as revealed by XPS. The obtained F-CNPs were tested in primary lithium battery. These materials allow to have higher OCV and to suppress the potential delay generally observed during the first time of the discharge reaction in commercial graphite fluorides. The discharge capacities observed at high rate $\left(1 \mathrm{C}\right.$ rate) were larger than those obtained with commercial $\mathrm{CF}_{\mathrm{x}}$. Nevertheless, in contrast with graphite fluorides, F-CNPs do not give rise to flat potential plateau but to a continuous decrease of the potential (sloppy shape), except at low rates such as C/100. Consequently, efforts should be pursued to improve the efficiency of fluorinated nano-carbon particles (F-CNPs).

\section{Conflicts of interest}

There are no conflicts to declare

\section{Acknowledgments}

The authors express their gratitude to those persons who have been involved during these last decades in these investigations: E. Durand, ICMCB-CNRS for fluorination experiments, Dr. C. Labrugère (PLACAMAT, CNRS-Université Bordeaux, France) for XPS investigations, Drs. A. Demourgues (ICMCB-CNRS) and D. Dambournet (Laboratoire PHENIX) for valuable discussions, S. Borensztjan (LISE, UPMC, France) and Dr. F. Warmont (CRMD, Orléans, France) for SEM and TEM investigations, respectively. F. Lantelme and C.M. Julien, (Laboratoire PHENIX, UPMC, France) are acknowledged for their scientific suggestions and advices, and A.-G. Porras-Gutierrez, K. Le Van, H. Mosqueda, S. Leclerc, and J. Gomes (Laboratoire PHENIX, UPMC, France) for their technical assistance.

\section{References}

1. N. Watanabe, M. Fukuda, US Patent 3536 532, 1970.

2. H. Touhara, H. Fujimoto, A. Tressaud, N. Watanabe, Discharge reaction mechanism in graphite fluoride-lithium batteries, Solid State Ionics 14 (1984), 163-170. 
3. N. Watanabe, T. Nakajima, H. Touhara, Preparation, stoichiometry and structure of graphite fluorides, in: Graphite Fluorides, Chap. 2, Elsevier: Amsterdam, 1988, pp. 23-89.

4. N. Watanabe, T. Nakajima, H. Touhara, Lithium-graphite fluoride battery, in: Graphite Fluorides, Chap. 5, Elsevier: Amsterdam, 1988, pp. 148-202.

5. T. Nakajima, Synthesis, structure, and physicochemical properties of fluorine-graphite intercalation compounds, in: Fluorine-carbon and fluoride-carbon materials, Chap. 1, M. Dekker: New York, 1995, pp. 1-31.

6. A. Tressaud, Synthesis and structures of main group fluoride- and transition metal fluoride-graphite intercalation compounds, in: Fluorine-carbon and fluoride-carbon materials, Chap. 2, M. Dekker: New York, 1995, pp. 32-66.

7. A. Tressaud, P. Dordor, E. Marquestaut, P. Hagenmuller, H. Fujimoto, S. Flandrois, Electrical properties of room-temperature fluorine intercalated graphite fibers. Synth. Metals, 40, (1991) 17 185.

8. H. Groult, C.M. Julien, A. Bahloul, S. Leclerc, E. Briot, A. Mauger, Improvements of the electrochemical features of graphite fluorides in primary lithium battery by electrodeposition of polypyrrole, Electrochem. Commun. 13 (2011), 1074-1076.

9. Y. Zhu, L. Zhang, H. Zhao, Y. Fu, Significantly improved electrochemical performance of $\mathrm{CF}_{\mathrm{x}}$ promoted by $\mathrm{SiO}_{2}$ modification for primary lithium batteries. J. Mater. Chem. A, 5 (2017) , 796-803.

10. A. Hamwi, P. Gendraud, H. Gaucher, S. Bonnamy, F. Béguin, Electrochemical properties of carbon nanotube fluoprides in a lithium cell system. Mol. Cryst. Liq. Cryst. 310 (1998) 185-190.

11. H. Touhara, J. Inahara, T. Mizuno, Y. Yokoyama, S. Okanao, K. Yanagiuch, I. Mukopadhyay, S. Kawasaki, F. Okino, H. Shirai, W.H. Xu, T. Kyotani, A. Tonita, Property control of new forms of carbon materials by fluorination. J. Fluorine Chem. 114 (2002), 181-188.

12. Y.-S. Lee, Synthesis and characterization of fluorinated carbon fibers and nanotubes, in: New fluorinated carbons: fundamentals and applications, Elsevier: Amsterdam, 2017, Chap. 6, , pp. 135154.

13. W. Zhang, M. Dubois, K. Guérin, P. Bonnet, H. Kharbache, F. Masin, P. Thomas, J.L. Mansot, A. Hamwi, Fluorinated nanocarbons using fluorinating agent: strategies of fluorination and applications. Eur. Phys. J. B 75 (2010) 133-139.

14. N. Nomède-Martyr, E. Disa, P. Thomas, L. Romana, J.L. Mansot, M. Dubois, K. Guérin, W. Zhang, A. Hamwi, Tribological properties of fluorinated nanocarbons with different shape factors. J. Fluorine Chem. 144 (2012), 10-16.

15. E.T. Mickelson, C.B. Huffman, A.G. Rinzler, R.E. Smalley, R.H. Hauge, J.L. Margrave, Fluorination of single-wall carbon nanotubes. Chem. Phys. Lett. 296 (1998) 188-194. 
16. N.F. Yudanov, A.V. Okotrub, Y.V. Shubin, L.I. Yudanova, L.G. Bulusheva, A.L. Chuvilin, J.-M. Bonard, Fluorination of arc-produced carbon material containing multiwall nanotubes, Chem. Mater. 14 (2002) 1472-1476.

17. M.M. Brzhezinskaya, N.A. Vinogradov, A. Zimina, V.E. Muradyan, Y.M. Shul'ga, A.S. Vinogradov, Characterization of fluorinated multiwalled carbon nanotubes with X-ray absorption, photoelectron and emission spectroscopies. Appl. Phys. A 94 (2009) 445-448.

18 Y. Li, Y. Feng, W. Feng, Deeply fluorinated multi-wall carbon nanotubes for high energy and power densities lithium/carbon fluorides battery, Electrochimica Acta, 107 (2013) 343-349.

19. Y. Ahmad, M. Dubois, K. Guerin, A. Hamwi, E. Flahaut, High energy density of primary lithium batteries working with sub-fluorinated few walled carbon nanotubes cathode, Journal of Alloys and Compounds, 726 (2017) 852-859.

20. Y. Yun, E. Broitman, A.J. Gellman, Oxidation of fluorinated amorphous (a-CF $\mathrm{CF}_{\mathrm{x}}$ films. Langmuir 26 (2010), 908-914.

21. C. Y. Dai, S. Cai, L. Wu, W. Yang, J. Xie, W. Wen, J-C. Zheng, Y. Zhu, Surface modified CF $x$ cathode material for ultrafast discharge and high energy density, J. Mater. Chem. A, 2 (2014), 20896.

22. D. L. Zhu, Y. Pan, L. Li, J. Zhou, W. Lei, J. Deng, Z. Ma, Preparation of CFx@C Microcapsules as a High-rate Capability Cathode of Lithium Primary Battery, Int. J. Electrochem. Sci, 11 (2016) 14 22.

23. Y. Xu, L. Zhan, Y. Wang, Y-I. Wang, Y-H. Shi, Fluorinated graphene as a cathode material for high performance primary lithium ion batteries, Front Chem. 2018 / Mar 9;6:50. doi: 10.3389/fchem.2018.00050.

24. G. Zhong, H. Chen, X. Huang, H. Yue, C. Lu, High-Power-Density, High-Energy-Density Fluorinated Graphene for Primary Lithium Batteries, Front. Chem., 09 March 2018 | https://doi.org/10.3389/fchem.2018.00050.

25. D. Damien, P. M. Sudeep, T. N. Narayanan, M. R. Anantharaman, P. M. Ajayan, M. M. Shaijumon, Fluorinated graphene based electrodes for high-performance primary lithium batteries, RSC Adv., 3 (2013) 25702.

26. S. Zhang, D. Foster, J. Read, Enhancement of discharge performance of Li/CFx cell by thermal treatment of $\mathrm{CF}_{\mathrm{x}}$ cathode material. J. Power Sources 188 (2009) 601-605.

27. S. Zhang, D. Foster, J. Read, Carbothermal treatment for the improved discharge performance of primary Li/CF $x$ battery. J. Power Sources 191 (2009) 648-652.

28. Q. Zhang, S. D’Astrog, P. Xiao, X. Zhang, L. Lu, Carbon-coated fluorinated graphite for high energy and high power densities primary lithium batteries. J. Power Sources 195 (2010) 2914-2917. 
29. K. Le Van, H. Groult, F. Lantelme, M. Dubois, D. Avignant, A. Tressaud, S. Komaba, N. Kumagai, S. Sigrist, Electrochemical formation of carbon nano-powders with various porosities in molten alkali carbonates, Electrochim. Acta 54 (2009) 4566-4573.

30. M. Winter, R.J. Brood, What are batteries, fuel cells, and supercapacitors? Chem. Rev. 104 (2004) 4245-4268.

31. P. Simon, Y. Gogotsi, Materials for electrochemical capacitors, Nature Mater. 7 (2008) 845-854.

32. J.R. Miller, P. Simon, Electrochemical Capacitor Design for Energy Management, Science 321 (2008) 651-652.

33. M.D. Ingram, B. Baron, G.J. Janz, The electrolytic deposition of carbon from fused carbonates. Electrochim. Acta, 11 (1966) 1629-1639.

34. Y. K. Delimarskii, V. I. Shapoval, V. A. Vasilenko, V. F, Grischenko, Otkrytiya, Izobret., Prom. Obraztsy, Tovarnye Znaki 52 (1975) 176.

35. Y. Ito, T. Shimada, H. Kawamura, in: Proceedings of the 8th International Symposium on Molten Salts, The Electrochem. Soc. Proc. Ser., Pennington: New Jersey, Volume PV 92-16 (1992) 574.

36. F. Lantelme, B. Kaplan, H. Groult, D. Devilliers, Mechanism for elemental carbon formation in molecular ionic liquids, J. Mol. Liquids 83 (1999) 255-269.

37. H. Kawamura, Y. Ito, Electrodeposition of cohesive carbon films on aluminum in a $\mathrm{LiCl}-\mathrm{KCl}-\mathrm{K}_{2} \mathrm{CO}_{3}$ melt, J. Appl. Electrochem. 30 (2000) 571-574.

38. C. Julien, Vibrational spectroscopy of electrode materials for rechargeable lithium batteries. I. Basic considerations, in: Proc. of the International Workshop Advanced Techniques for Energy Sources Investigation and Testing, Sofia, Bulgaria, sept. 2004.http://citeseerx.ist.psu.edu/viewdoc/download?doi=10.1.1.555.8650\&rep=rep1\&type=pdf

39. C. Julien, K. Zaghib, A. Mauger, M. Massot, A. Ait-Salah, M. Selmane, F. Gendron, Characterization of the carbon coating onto $\mathrm{LiFePO}_{4}$ particles used in lithium batteries. J. Appl. Phys. 100 (2006) 63511.

40. T. Nakajima, Synthesis, structure, and physicochemical properties of fluorine-graphite intercalation compounds, in: Fluorine-carbon and fluoride-carbon materials, Chap. 1, M. Dekker: New York, 1995, pp. 1-31.

41. C. Delabarre, M. Dubois, J. Giraudet, K. Guerin, R. Yazami, A. Hamwi, Comparative electrochemical study of low temperature fluorinated graphite used as cathode in primary lithium batteries, ECS Trans. 36 (2007) 153-163.

42. Y. Sato, K. Itoh, R. Hagiwara, Y. Ito, Short-range structures of poly(dicarbon monofluoride) $\left(\mathrm{C}_{2} \mathrm{~F}\right)_{n}$ and poly(carbon monofluoride) (CF) $)_{n}$, Carbon 42 (2004) 2897-2903.

43. Z. Wang, J. Wang, Z. Li, P. Gong, X. Liu, L. Zhang, J. Ren, H. Wang, S. Yang, Synthesis of fluorinated graphene with tunable degree of fluorination, Carbon 50 (2012) 5403-5410. 
44. K. Guérin, M. Dubois, A. Houdayer, A. Hamwi, Applicative performances of fluorinated carbons through fluorination routes: A review. J. Fluorine Chem. 134 (2010) 11-17.

45. P. Lam, R. Yazami, Physical characteristics and rate performance of $(\mathrm{CF} x) n(0.33<x<0.66)$ in lithium batteries. J. Power Sources 153 (2006) 354-359.

46. G. Nagasubramanian, K. Fentin, Electrochemical characterization of CFx material for an internally funded project. 224 ${ }^{\text {th }}$ ECS Meeting Abstr., (2013) Abstr. \#265.

47. G. Nagasubramanian, Fabrication and testing capabilities for $18650 \mathrm{Li} /\left(\mathrm{CF}_{\mathrm{x}}\right)_{\mathrm{n}}$ cells. Int. J. Electrochem. Sci. 2 (2007) 913-922. 